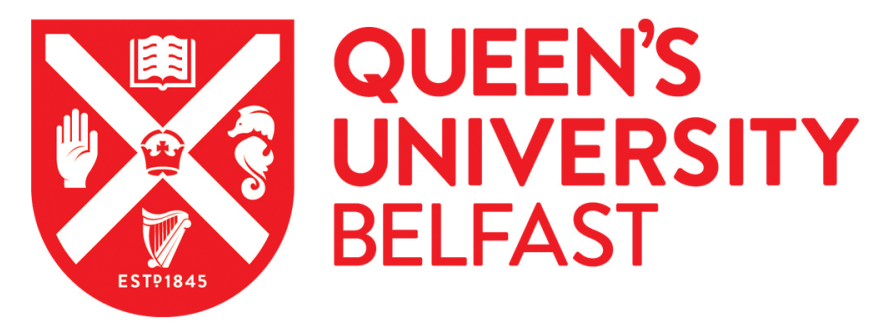

\title{
Constraining the age of Lateglacial and early Holocene pollen zones and tephra horizons in southern Sweden with Bayesian probability
} methods

Wohlfarth, B., Blaauw, M., Davies, S., Andersson, M., Wastegard, S., Hormes, A., \& Possnert, G. (2006).

Constraining the age of Lateglacial and early Holocene pollen zones and tephra horizons in southern Sweden with Bayesian probability methods. Journal of Quaternary Science, 21(4), 321-334.

https://doi.org/10.1002/jqs.996

Published in:

Journal of Quaternary Science

Document Version:

Publisher's PDF, also known as Version of record

Queen's University Belfast - Research Portal:

Link to publication record in Queen's University Belfast Research Portal

\section{General rights}

Copyright for the publications made accessible via the Queen's University Belfast Research Portal is retained by the author(s) and / or other copyright owners and it is a condition of accessing these publications that users recognise and abide by the legal requirements associated with these rights.

Take down policy

The Research Portal is Queen's institutional repository that provides access to Queen's research output. Every effort has been made to ensure that content in the Research Portal does not infringe any person's rights, or applicable UK laws. If you discover content in the

Research Portal that you believe breaches copyright or violates any law, please contact openaccess@qub.ac.uk. 


\title{
Constraining the age of Lateglacial and early Holocene pollen zones and tephra horizons in southern Sweden with Bayesian probability methods
}

\author{
B. WOHLFARTH, ${ }^{1}{ }^{*}$ M. BLAAUW, ${ }^{2}$ S. M. DAVIES, ${ }^{3}$ M. ANDERSSON, ${ }^{1}$ S. WASTEGÅRD, ${ }^{1}$ A. HORMES ${ }^{4}$ and G. POSSNERT ${ }^{4}$ \\ ${ }^{1}$ Department of Physical Geography and Quaternary Geology, Stockholm University, Stockholm, Sweden \\ ${ }^{2}$ Centro de Investigación en Matemáticas, Guanajuato, Mexico \\ ${ }^{3}$ Department of Geography, University of Wales Swansea, Swansea, UK \\ ${ }^{4}$ Ångström Laboratory, Uppsala University, Uppsala, Sweden
}

Wohlfarth, B., Blaauw, M., Davies, S. M., Andersson, M., Wastegård, S., Hormes, A. and Possnert, G. 2006. Constraining the age of Lateglacial and early Holocene pollen zones and tephra horizons in southern Sweden with Bayesian probability methods. J. Quaternary Sci., Vol. 21 pp. 321-334. ISSN 0267-8179.

Received 17 July 2004; Revised 28 October 2005; Accepted 9 November 2005

\begin{abstract}
The sediment sequence from Hässeldala port in southeastern Sweden provides a unique Lateglacial/early Holocene record that contains five different tephra layers. Three of these have been geochemically identified as the Borrobol Tephra, the Hässeldalen Tephra and the 10-ka Askja Tephra. Twenty-eight high-resolution ${ }^{14} \mathrm{C}$ measurements have been obtained and three different age models based on Bayesian statistics are employed to provide age estimates for the five different tephra layers. The chrono- and pollen stratigraphic framework supports the stratigraphic position of the Borrobol Tephra as found in Sweden at the very end of the Older Dryas pollen zone and provides the first age estimates for the Askja and Hässeldalen tephras. Our results, however, highlight the limitations that arise in attempting to establish a robust, chronologically independent lacustrine sequence that can be correlated in great detail to ice core or marine records. Radiocarbon samples are prone to error and sedimentation rates in lake basins may vary considerably due to a number of factors. Any type of valid and 'realistic' age model, therefore, has to take these limitations into account and needs to include this information in its prior assumptions. As a result, the age ranges for the specific horizons at Hässeldala port are large and calendar year estimates differ according to the assumptions of the age-model. Not only do these results provide a cautionary note for overdependence on one age-model for the derivation of age estimates for specific horizons, but they also demonstrate that precise correlations to other palaeoarchives to detect leads or lags is problematic. Given the uncertainties associated with establishing age-depth models for sedimentary sequences spanning the Lateglacial period, however, this exercise employing Bayesian probability methods represents the best possible approach and provides the most statistically significant age estimates for the pollen zone boundaries and tephra horizons. Copyright (c) 2006 John Wiley \& Sons, Ltd.
\end{abstract}

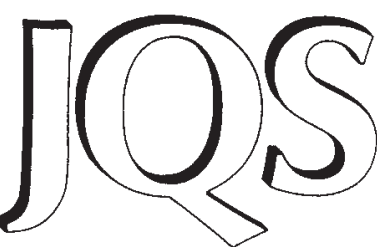

Journal of Quaternary Science

KEYWORDS: Lateglacial; early Holocene; Borrobol Tephra; Hässeldalen Tephra; 10-ka Askja Tephra; Bayesian age-depth modelling; pollen stratigraphy; southeast Sweden.

\section{Introduction}

The Weichselian Lateglacial and the early Holocene were characterised by rapid, short-term climatic variations, seen in numerous geological archives around the Northern Hemisphere. Hypotheses to explain these rapid climate fluctuations, which had a distinct impact on terrestrial and marine environ-

* Correspondence to: B. Wohlfarth, Department of Physical Geography and Quaternary Geology, Stockholm University, 10691 Stockholm, Sweden. E-mail: Barbara.Wohlfarth@geo.su.se ments, focus on internal factors (e.g. changes in the thermohaline circulation) (Björck et al., 1996; Broecker, 1998, 2003; Hughen et al., 1998, 2000) as well as external factors (e.g. solar forcing) (Björck et al., 2001; Bond et al., 2001; Goslar et al., 2000; Renssen et al., 2000; van der Plicht et al., 2004). However, to understand the trigger or forcing mechanism that may have initiated these rapid climate changes, it is crucial to map their spatial occurrence and timing and to link the changes observed in different archives on a common and high-resolution timescale. This approach would help decipher the environmental impact of climatic fluctuations in different regions and would enable the testing of hypotheses of synchroneity/asynchroneity between different records. 
This seemingly straightforward procedure is, however, limited by problems of radiocarbon dating marine and terrestrial sequences during this time interval (e.g., Gulliksen et al., 1998; Lowe and Walker, 2000; Björck and Wohlfarth, 2001; Björck et al., 2003) and by the paucity of annually resolved archives. Recommendations by the INTIMATE group ${ }^{1}$ to solve some of these issues include the use of the Greenland Ice Core (GRIP) event stratigraphy as a template and the search for timesynchronous tephra horizons in ice cores and marine and terrestrial records (Björck et al., 1998; Walker et al., 1999; Lowe et al., 2001; Walker, 2001). By correlating chronologically well-constrained sequences to the GRIP template, leads or lags in environmental response as inferred from palaeoarchives in different regions may be evaluated.

Techniques for the detection of tephra layers have changed considerably over the last 10 years with the detection of cryptotephras (Lowe and Hunt, 2001) (horizons that contain a low concentration of volcanic glass shards, all or most of which are $<100 \mu \mathrm{m}$ in size) in areas far more distal to the source volcanoes than previously realised. Cryptotephras can be used as time-synchronous marker horizons if the fallout occurred within one or two years, there has been no reworking or geochemical alteration of the volcanic ash after deposition and the tephras have well characterised geochemical signatures. The introduction of extraction techniques, particularly a density separation method for minerogenic sediments (Turney, 1998b) has greatly extended the geographical distribution of some Lateglacial rhyolitic tephras that were previously delimited by visible occurrences in proximal areas. For instance, the Vedde Ash (10 $300{ }^{14} \mathrm{C}$ yr BP; Birks et al., 1996; Wastegård et al., 1998) has now been traced into lacustrine sediments in Scotland, Sweden, Arctic Norway, northwest Russia and the Netherlands (Turney et al., 1997; Wastegård et al., 1998, 2000a,b; Davies et al., 2005; Pilcher et al., 2005). In addition, careful examination of sequences has revealed the presence of new, previously undetected tephras that are currently only identified in cryptotephra form. One such example is the Borrobol Tephra, initially identified in Scottish lacustrine sequences (Turney et al., 1997) but subsequently detected within marine sediments from the Icelandic plateau (Eiriksson et al., 2000) and terrestrial records in southern Sweden-one of which is under investigation here (Davies et al., 2003). The discovery of the Borrobol Tephra not only provides an additional marker horizon for correlation purposes during the early Lateglacial but adds considerably to our knowledge of the European tephrochronology framework during this time. A number of other so-called 'new' tephras of Lateglacial age have been identified in the last few years (e.g. Eiriksson et al., 2000; Haflidason et al., 2000; Davies et al., 2003; Mortensen et al., 2005), and thus at present over 30 tephras from the four main volcanic provinces in Europe, are potentially available for precise correlation of terrestrial, marine and ice-core sequences that span the Lateglacial and early Holocene (Davies et al., 2002).

The application of tephrochronology, however, is not without problems, as exemplified by the Lateglacial/early Holocene lake sediment sequence discovered at Hässeldala port in southernmost Sweden (Fig. 1). This $77 \mathrm{~cm}$ long sequence provides a unique Lateglacial record containing five distinct tephra layers, three of which have been geochemically identified as the Borrobol Tephra (BT), the Hässeldalen Tephra (HDT) and the 10-ka Askja Tephra (AsT) (Davies et al., 2003). The remaining geochemically unidentified tephra horizons have been tentatively

${ }^{1}$ INTegration of Ice core Marine and TErrestrial records during the Last Termination-a core programme of the International Union for Quaternary Research (INQUA) Palaeoclimate Commission. assigned to the Laacher See and Vedde Ash fallout, respectively (Davies et al., 2003). In a previous publication we presented arguments, based on pollen and radiocarbon evidence, for an age assignment of the BT at the late Older Dryas/very early Allerød (GI-1d/GI-1c) boundary (Davies et al., 2004b), which contrasts with British and Icelandic records indicating tephra deposition around the Oldest Dryas/Bølling transition (GS-2/ GI-1) (Turney et al., 1997; Lowe et al., 1999; Eiriksson et al., 2000). This age discrepancy has raised the possibility that there may have been more than one BT, indistinguishable by major element geochemistry, deposited during this time interval (Davies et al., 2004b). Indeed, recently published evidence for a 'Borrobol-like tephra' horizon in a Scottish lake sediment sequence dating to ca. $13610 \mathrm{cal}$.yr BP and attributed to the early Allerød (Ranner et al., 2005), seems to lend support to this hypothesis. The possible presence of two geochemically identical ash layers during this time period emphasises that regional tephrochronology frameworks need to be underpinned by supplementary geochemical data (e.g. trace and rare earth element analysis) and by a comprehensive chrono- and pollen stratigraphic framework (Turney et al., 2004).

Although the age of the BT as identified at Hässeldala port has been discussed in detail elsewhere (Davies et al., 2004b), the aim of this article is to employ a more comprehensive ${ }^{14} \mathrm{C}$ data set to re-address the BT age estimate and provide ages for the remaining tephras found at this site. First we present a correlation of the local pollen assemblage zones to the regional pollen stratigraphy for southern Sweden, so that the tephra layers are placed within a regional context. Secondly, we employ three different age-depth models based on Bayesian statistics and evaluate their ability to provide a robust chronostratigraphic framework for the tephra layers and the Lateglacial pollen zone boundaries.

\section{Methods}

Sediment cores were obtained at Hässeldala port during the spring of 2001 (cores 1 and 2) and during the autumn of 2002 (core 3) with a Russian corer $(7.5 \mathrm{~cm}$ diameter, $1 \mathrm{~m}$ length) (Fig. 1(C)). The cores were wrapped in plastic and kept in cold storage until sampling was undertaken. The first tephrochronological investigations performed on core 1 and reported by Davies et al. (2003) clearly showed the potential of the site for further and more detailed investigations. As a follow-up study, sub-sampling for total carbon (TC) was undertaken on cores 1, 2 and 3, terrestrial plant macrofossils for AMS ${ }^{14} \mathrm{C}$ measurements were extracted from core 2 and samples for pollen analysis were taken from core 3 . In addition, the stratigraphic position of the cryptotephras was determined for cores 2 and 3 to aid core correlations.

TC was measured in contiguous $1-\mathrm{cm}$ samples using a CS 500 carbon/sulphur analyser. Cryptotephra investigations of the minerogenic Lateglacial sediment followed the density separation method outlined in Turney (1998a) and the more organic early Holocene sediments were subjected to the ashing technique and dilute alkali treatment outlined by Pilcher and Hall (1992), Pilcher et al. (1996) and Rose et al. (1996), respectively. Samples prepared for microprobe analyses were subjected to an acid digestion technique (Dugmore et al., 1995) and the geochemical results are reported in Davies et al. (2003).

Pollen preparation followed the methods outlined in Berglund and Ralska-Jasiewiczowa (1986). Pollen and spores were counted at $\times 400$ magnification and identified with the 


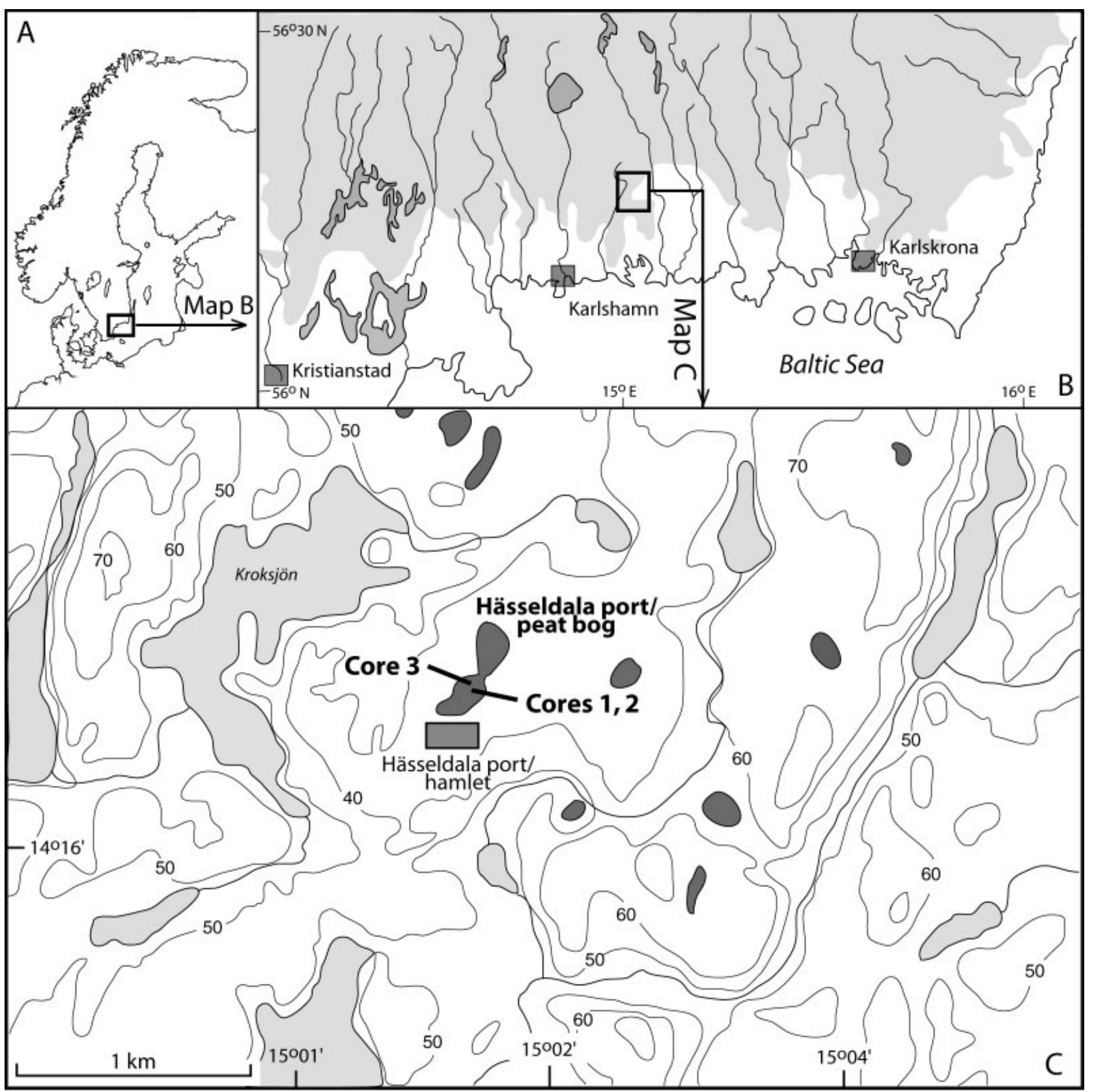

Figure 1 (A) Scandinavia; (B) the location of the site Hässeldala port in southeast Sweden; and (C) topographic map of the site, including coring points 1-3. (B) shaded areas = areas above the Highest Coastline (ca. $60 \mathrm{~m}$ a.s.l.); dark grey $=$ lakes. $(\mathrm{C})$ light grey $=$ lakes; dark grey= peat bogs

aid of keys in Moore et al. (1991) and in comparison with the reference collections at the Department of Physical Geography and Quaternary Geology, Stockholm University. The pollen diagram was constructed in Tilia and Tilia Graph (Grimm, 1991, 1992) and the local pollen assemblage zones (LPAZ) HÄP 1-7 were established with CONISS (Grimm, 1987).

Sediment slices 1 to $3 \mathrm{~cm}$ thick were sieved ( $0.25 \mathrm{~mm}$ mesh) under running water and a low-powered dissecting microscope was used to select and identify terrestrial plant macrofossils. The samples were placed in clean glass bottles, dried at $110^{\circ} \mathrm{C}$ and analysed with the EN-tandem accelerator (Possnert, 1990) at Uppsala University. Pre-treatment followed the standard acid-alkali-acid procedure (Björck and Wohlfarth, 2001). However, two of the small samples (Ua-16761 and Ua-16766) were only pretreated with $10 \% \mathrm{HCl}$ because alkali treatment would have led to loss of material. Prior to the accelerator measurement the dried material $(\mathrm{pH} 4)$ was combusted to $\mathrm{CO}_{2}$ and converted to graphite using a Fe-catalyst reaction. A small fraction of approximately $0.05 \mathrm{mg}$ carbon of the $\mathrm{CO}_{2}$ gas was used for measurement of the natural mass fractionation, $\delta^{13} \mathrm{C}$, in a conventional mass spectrometer (VG OPTIMA).

During periods with highly variable atmospheric ${ }^{14} \mathrm{C}$ concentrations, calibration of individual dates results in very large possible calendar age intervals. To constrain the calibrated ranges, sequences of closely spaced ${ }^{14} \mathrm{C}$ dates can be calibrated simultaneously against the calibration curve IntCal04 (Reimer et al., 2004) in a Bayesian framework using assumptions such as linear accumulation rate or chronological ordering. Three different age-models $(\mathrm{A}-\mathrm{C})$ were constructed using Bayesian calibration approaches, which match ${ }^{14} \mathrm{C}$ dates to the IntCal04 calibration curve, using prior information specified below, but excluding biostratigraphical information. Model A (using the software Bpeat) (Blaauw and Christen, 2005) assumes linear accumulation of the entire sequence and a prior probability of $5 \%$ of a ${ }^{14} \mathrm{C}$ date being an outlier. ${ }^{14} \mathrm{C}$ measurements derived from corroded plant remains were, however, given a much higher prior outlier probability of $50 \%$. Model $\mathrm{B}$ uses the same assumptions as model A, but divides the 
${ }^{14} \mathrm{C}$ sequence into three sections, which are wiggle-matched against the radiocarbon calibration curve, allowing for shortlasting hiatuses of up to $100 \mathrm{yr}$. Bpeat has an in-built dependency of accumulation rates between sections. Given the large possible accumulation rate variations of the sequence, the dependency was here set at very low levels (effectively assuming no dependence of accumulation rates between sections). Model $\mathrm{C}$ does not assume linear accumulation, but uses the less stringent assumption of chronological ordering of the dated levels, i.e. the calendar age increases with depth. Prior outlier probabilities were set at $50 \%$ for ${ }^{14} \mathrm{C}$ measurements on corroded plant material, and at $5 \%$ for the other dates, as in models B and C. Calculations were performed using Bcal (Buck et al., 1999).

\section{Results}

Lithostratigraphy, core correlation, tephra horizons and pollen stratigraphy

Cores 1, 2 and 3 were correlated with each other by lithostratigraphy, stratigraphic marker horizons and wiggle-matching of the high-resolution TC curves (Fig. 2). The correlation shows that the sedimentation rates in cores 1 and 2 are comparable, whereas core 3 , which is the longest and deepest sequence, has higher sedimentation rates. Such marked differences between nearby sequences are fairly common for small Lateglacial basins in southern Sweden, where erosion and bedrock topography has a strong influence on the sedimentation rate.

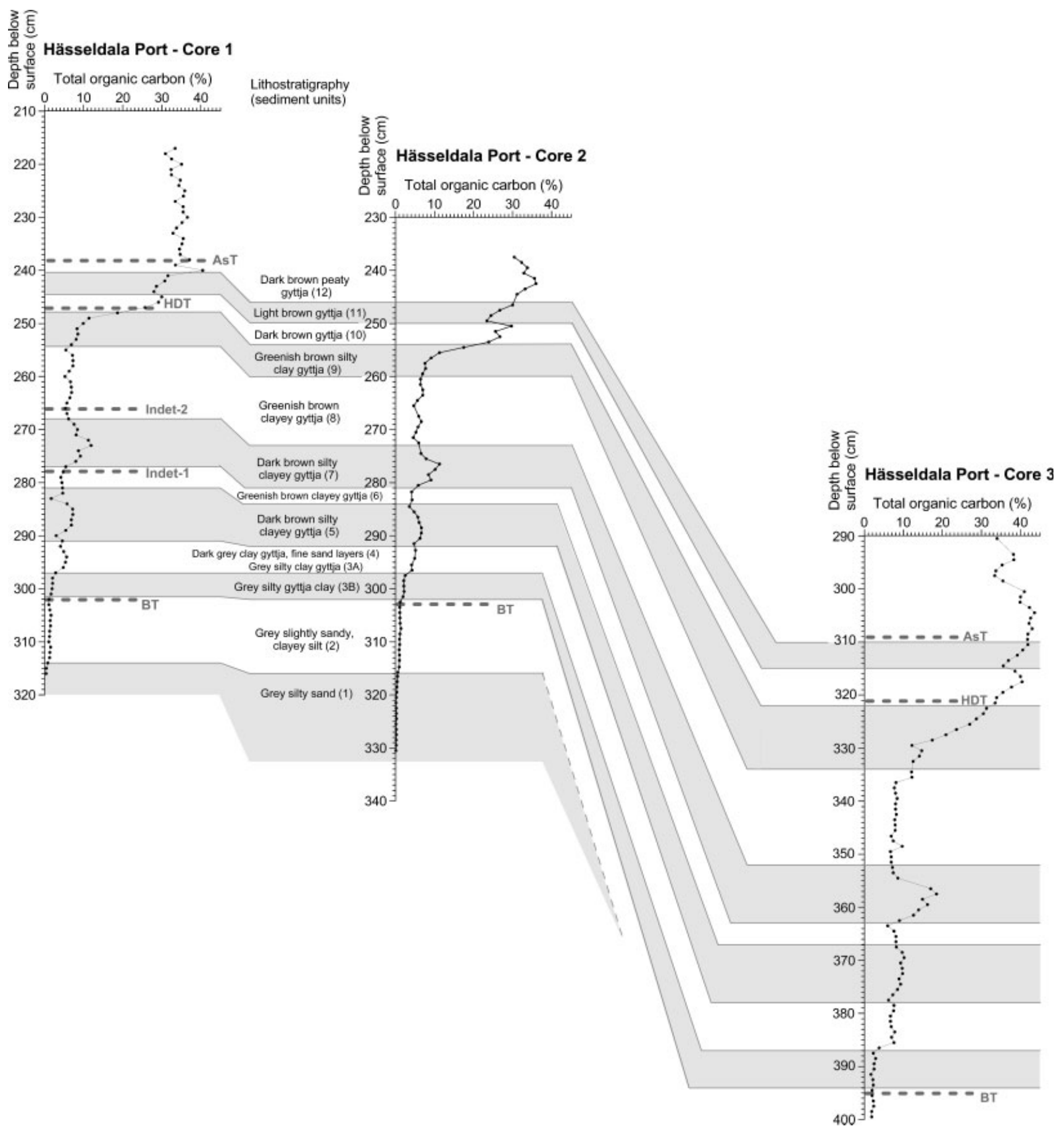

Figure 2 Lithostratigraphy and total organic carbon curves for sediment cores 1,2 and 3 from Hässeldala port. The correlation between the three cores is based on wiggle-matching the TC curves. The cryptotephra layers found in the three sequences are indicated by dashed lines. BT $=$ Borrobol Tephra, Indet. = unidentified tephra, HDT = Hässeldalen tephra, AsT = Askja Tephra 

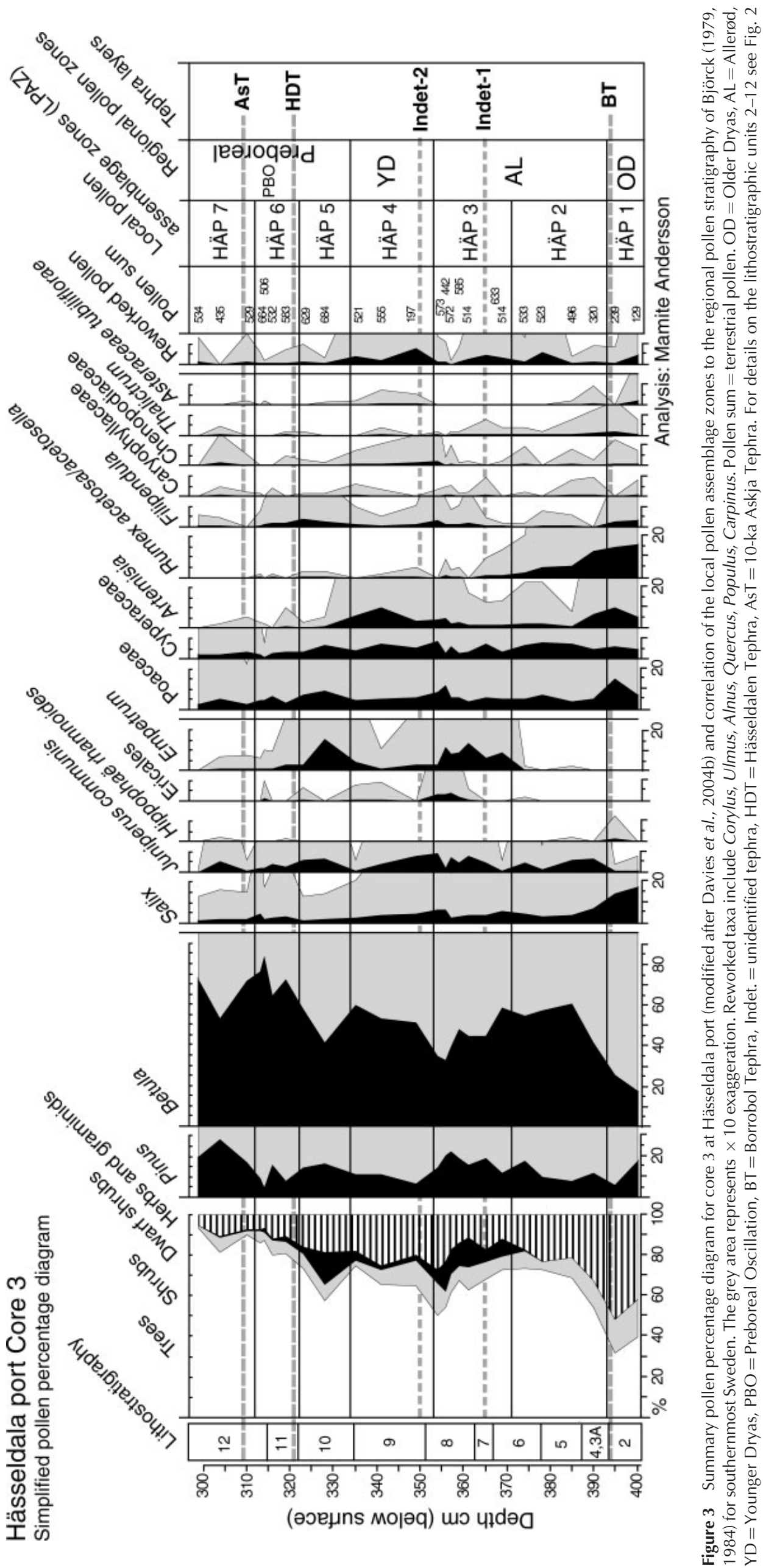
All three cores show a gradual increase in TC content in the basal sandy, silty and clayey sediments (units 1, 2, 3B), a more marked increase at the transition to the clay gyttja in unit $3 \mathrm{~A}$, fluctuating values in the gyttja layers of units 4 and 5 and a slight decrease in unit 6 . Subsequent to the distinct peak in unit 7, TC declines and has fairly low and stable values in unit 8 . The renewed, rapid increase in TC during unit 9 is followed by high, but fluctuating values in units 10-12 (Fig. 2). These fluctuations include a distinct TC minima in sediment unit 11 at 244-241 cm (core 1), 250-248 cm (core 2) and 316-313 cm (core 3), respectively. TC is generally assumed as a measure of lake productivity and intervals with lower/higher values may thus correspond to periods with lower/higher lake productivity.

Geochemical identification of the tephra horizons was undertaken on samples from core 1 and the results are reported in Davies et al. (2003). Only the peak shard concentrations were determined in cores 2 and 3. The BT occurs at a depth of $303 \mathrm{~cm}$ in core 1, at $302 \mathrm{~cm}$ in core 2 and at $394 \mathrm{~cm}$ in core 3 , just below the transition between sediment units 2 and 3B (Fig. 2). The two unidentified tephra layers were only detected in core 1 at depths of $278 \mathrm{~cm}$ (sediment unit 6) and $266 \mathrm{~cm}$ (sediment unit 8) respectively. Low shard concentration (Davies et al., 2003) and the uneven distribution of tephra horizons in general, may explain why these cryptotephras were not found in cores 2 and 3. The HDT, found in core 1 at 247 $\mathrm{cm}$ and in core 3 at $321-322 \mathrm{~cm}$, lies on the slope of the increasing TC curve, at the transition between sediment units 9 and 10. The youngest tephra of the Hässeldala sequence, the AsT occurs at a depth of $238 \mathrm{~cm}$ in core 1 and at 308$310 \mathrm{~cm}$ in core 3 .

The pollen stratigraphy, which was established on core 3 (Fig. 3), covers the sediments between 400 and $300 \mathrm{~cm}$ depth and thus extends from the middle part of sediment unit 2 to sediment unit 12. The LPAZs HÄP 1-7 are described in Table 1 and correlated to the regional pollen stratigraphy for southeast Sweden (Björck, 1979; Björck and Möller, 1987; Björck et al., 1996). The correlation shows that the analysed part of the sequence encompasses the regional Older Dryas, Allerød, Younger Dryas and Preboreal pollen zones. A distinct characteristic of the Older Dryas pollen zone in southeast
Sweden is the first occurrence of Hippophaë pollen (HÄP 1), which is followed by an increase in Juniperus (Allerød I) and Empetrum pollen percentages (Allerød II) (HÄP 2, 3) (Björck, 1979, 1984) (Fig. 3). The distinct increase in Artemisia pollen values along with a decline in Empetrum (HÄP 4), can be observed in all south Swedish pollen diagrams covering this time interval and marks the Younger Dryas pollen zone (Berglund et al., 1994; Björck et al., 1996). The renewed rise in Empetrum pollen percentages and the coincident decline in Artemisia pollen values (LPAZ HÄP 5) has formerly been attributed to the upper part of the Younger Dryas pollen zone and was named YD III (Björck, 1979; Björck and Möller, 1987) or 'Younger Dryas-Preboreal transition zone', but is now assigned to the beginning of the Preboreal pollen zone (Björck et al., 1996). High pollen values for Betula and Pinus and a decrease of non-arboreal pollen (LPAZ HÄP 6, 7) are characteristic of the middle and upper part of the Preboreal pollen zone. In addition, the distinct increase in Salix pollen values at $314 \mathrm{~cm}$ in HÄP 6, which coincides with a decline in Pinus pollen percentages (Fig. 3), can be related to the Preboreal Oscillation (PBO) as defined by Björck et al. (1997) for southern Sweden.

The LPAZs established on core 3 can be tentatively transferred to cores 1 and 2 through a correlation of the three TC curves (Figs 2 and 4). This correlation indicates that a minor increase in TC in all three cores and thus in lake productivity occurred before and during the Older Dryas pollen zone. Lake productivity increased during Allerød I, but declined again shortly in Allerød II. This decline could possibly be associated with the so-called 'Gerzensee Oscillation' (Lotter et al., 1992; Andresen et al., 2000). The distinct peak in TC visible in all three cores during the upper part of $\mathrm{HÄP} 3$ is characteristic for many lake sediment sequences in south Sweden (Berglund et al., 1994). It may reflect increased lake productivity, but could also be due to increased inwash of terrestrial plant material. During the regional Younger Dryas pollen zone inferred lake productivity remained low, but increased again rapidly during the early Preboreal (Fig. 4). A phase with distinctly lower TC values is visible in HÄP $6(244-241 \mathrm{~cm}$ in core 1; $250-248 \mathrm{~cm}$ in core $2 ; 316-313 \mathrm{~cm}$ in core 3 ) and coincides

Table 1 Correlation of the local pollen assemblage zones (LPAZ) at Hässeldala port, core 3 with the regional pollen stratigraphy for Blekinge, southeast Sweden (Björck, 1979; Björck and Möller, 1984). The original YD III pollen zone is now placed within the Preboreal pollen zone (Björck et al., 1996). $\mathrm{PBO}=$ Preboreal Oscillation according to Björck et al. (1997)

\begin{tabular}{|c|c|c|c|}
\hline LPAZ & Depth $(\mathrm{cm})$ & Description & Regional pollen zone \\
\hline Ḧ̈P 7 & $312-300$ & $\begin{array}{l}\text { Pinus-Juniperus zone } \\
\text { Marked increase of Pinus and high values of Betula }\end{array}$ & Preboreal \\
\hline HÄP 6 & $322-312$ & $\begin{array}{l}\text { Betula zone } \\
\text { Low herb and shrub pollen values, dominance of Betula; } \\
\text { distinct increase of Salix and decrease of Pinus in upper } \\
\text { part of the zone }\end{array}$ & Preboreal, incl. PBO \\
\hline Ḧ̈Р 5 & $334-322$ & $\begin{array}{l}\text { Empetrum-Juniperus-Poaceae zone } \\
\text { Increase in Pinus, distinct Empetrum peak, increase } \\
\text { Juniperus, decrease of Artemisia }\end{array}$ & $\begin{array}{l}\text { Younger Dryas/YD III } \\
\text { Preboreal }\end{array}$ \\
\hline HÄP 4 & $355-334$ & $\begin{array}{l}\text { Artemisia-Betula-Juniperus zone } \\
\text { Increase in herb and shrub pollen, high Betula, but low } \\
\text { Pinus. Distinct decrease in Empetrum and marked increase } \\
\text { in Artemisia }\end{array}$ & Younger Dryas/YD I, II \\
\hline HÄP 3 & $371-355$ & $\begin{array}{l}\text { Empetrum-Pinus-Betula zone } \\
\text { High Betula and Pinus and low herb pollen values, } \\
\text { distinct increase in Empetrum }\end{array}$ & Allerød/AL II \\
\hline Ḧ̈Р 2 & $393-371$ & $\begin{array}{l}\text { Betula-Rumex zone } \\
\text { Herb and grass pollen values decrease and Juniperus and } \\
\text { tree pollen values increase }\end{array}$ & Allerød/AL I \\
\hline HÄP1 & $400-393$ & $\begin{array}{l}\text { Rumex-Salix-Artemisia-Poaceae zone } \\
\text { High frequencies of herb, graminid, shrub pollen, } \\
\text { low values of tree pollen; first occurrence of Hippophaë }\end{array}$ & Older Dryas \\
\hline
\end{tabular}



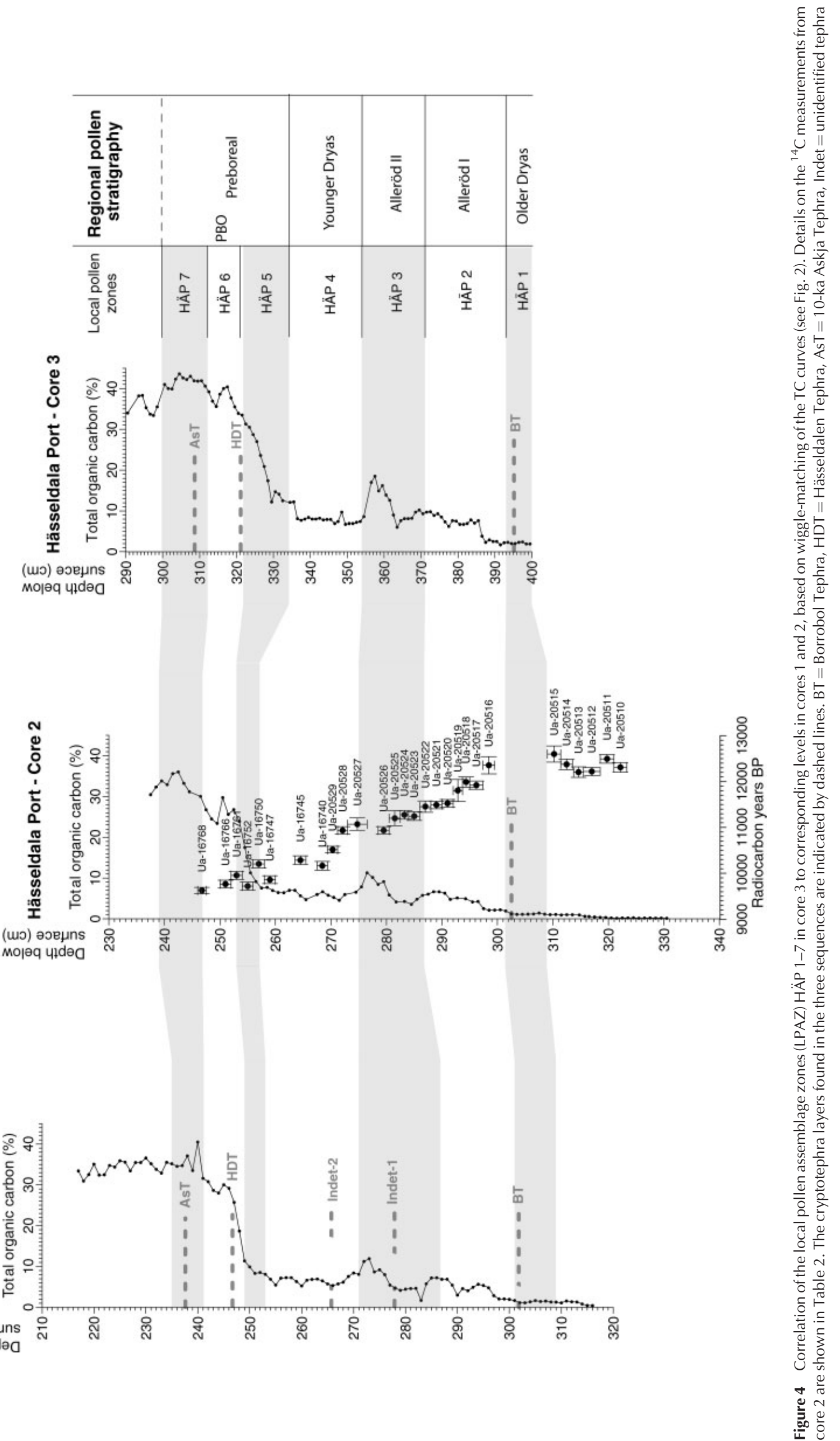

(us) eoejuns

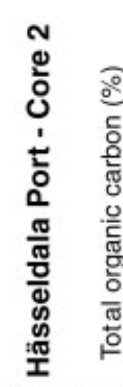
мо|әq ułded mojəq uıdea
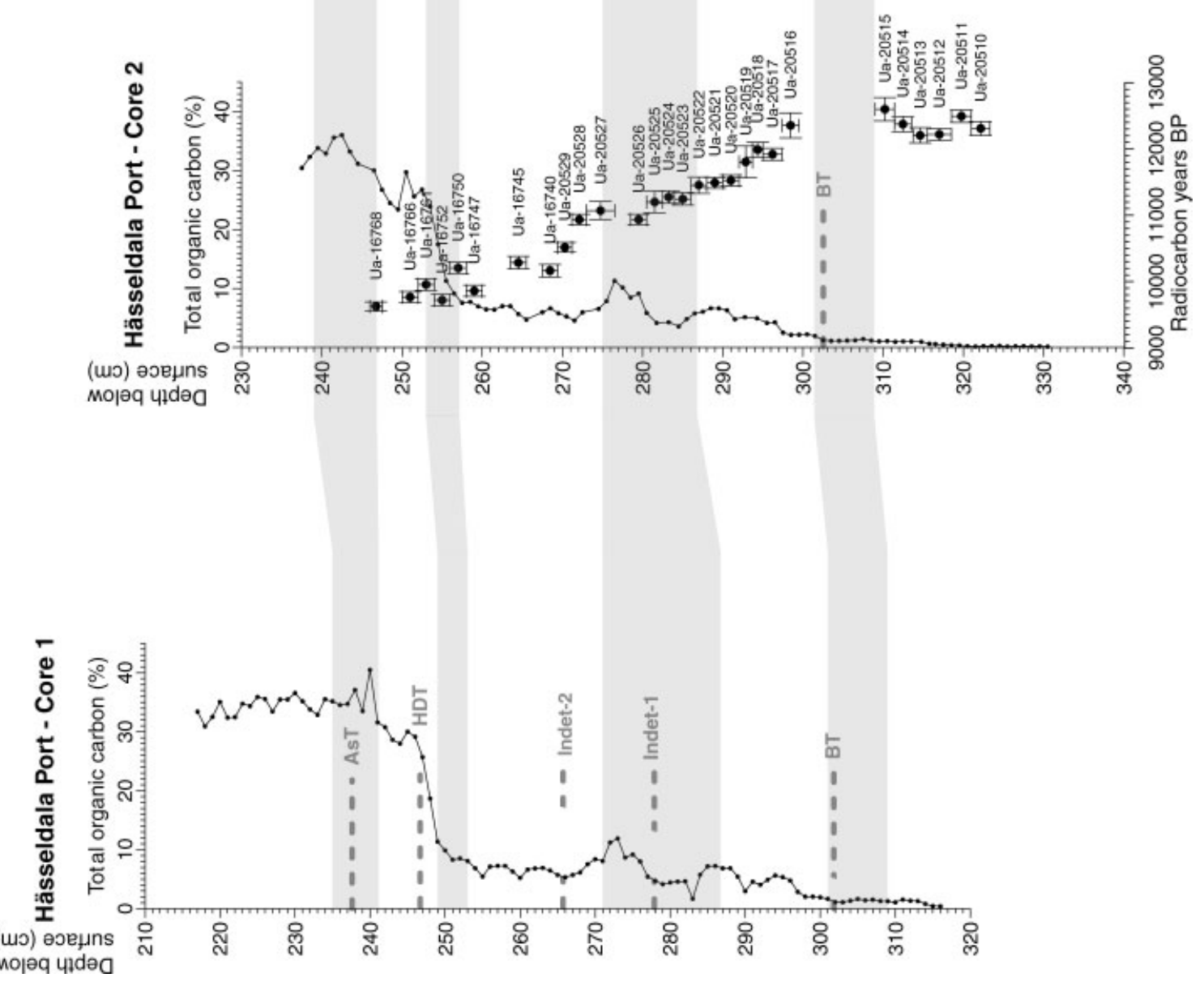
with the change in pollen spectra discussed above and attributed to the PBO.

The correlation between cores 1-3 (Fig. 4) shows that the BT falls at the very end of the Older Dryas pollen zone as discussed previously by Davies et al. (2004b). The older of the two unidentified cryptotephras (Indet-1), discovered in core 1, occurs in the Allerød II pollen zone, during an interval with lower TC values, which may correspond to the Gerzensee Oscillation. The second unidentified tephra (Indet-2) is assigned to the early part of the Younger Dryas pollen zone and the two youngest tephras (HDT, AsT) to the Preboreal pollen zone. The HDT, which has been found in cores 1 and 3, occurs shortly before the PBO and the AsT falls shortly after the PBO.

\section{Age models}

The radiocarbon ages obtained earlier on core 2, between 323 and $270 \mathrm{~cm}$ depth (Davies et al., 2004b) are here supplemented by eight new measurements between 270 and $246 \mathrm{~cm}$. A total of 28 radiocarbon measurements are thus available for the entire sequence, ranging from ca. 12600 to ca. 9600 ${ }^{14} \mathrm{C}$ yr BP (Table 2). Plotted against depth, the ${ }^{14} \mathrm{C}$ dates follow the general trend of Lateglacial and early Holocene ${ }^{14} \mathrm{C}$ variations with several short and longer ${ }^{14} \mathrm{C}$ plateaux (Reimer et al., 2004) (Fig. 4). The age-depth curve, however, indicates that some of the measurements may have yielded ages that are too old (Ua-20511, 20514, 20515, 20516) or too young (Ua-16740, 16747, 16752). Indeed, samples Ua-20514, 20515 and 20516 contained heavily corroded leaves and leaf fragments (Table 2), which are most likely reworked from older sediments. Samples that appear to have too young ages may be related to small sample size which increases the possibility of contamination by recent material (Wohlfarth et al., 1998).

In model $\mathrm{A}$ the ${ }^{14} \mathrm{C}$ measurements were wiggle-matched to the IntCal04 calibration curve (Reimer et al., 2004) in the program Bpeat (Blaauw and Christen, 2005), by assuming linear accumulation of the entire sequence and excluding lithostratigraphic information (Fig. 5(a) and (d)). Prior assumptions were that (i) accumulation rates range between ca. 20 and $80 \mathrm{y} \mathrm{cm}^{-1}$, but that lower and higher accumulation rates are possible, albeit less likely; and (ii) prior outlier probabilities were $50 \%$ for those measurements which included corroded plant material (Table 2), and 5\% for other measurements. Model results show that not all ${ }^{14} \mathrm{C}$ dates (1 s.d. error bars) overlap with the IntCal04 calibration curve (Fig. 5(a)) and that the fit $\mathrm{F}$ is $83.84 \%$ (see Blaauw and Christen, 2005). In particular, ${ }^{14} \mathrm{C}$ dates Ua-16752, Ua-16747, Ua-20528, Ua-20527, Ua-20520, Ua-20516, Ua-20512 and Ua-20510 obtained high posterior probabilities of being outliers, while of these dates only Ua-20520 and Ua-20516 contained corroded plant material (Table 2). Other dates with corroded plant material (Ua20514 and Ua-20515) fall on the calibration curve. The estimated accumulation rate for the entire sequence was ca. $53 \mathrm{yr} \mathrm{cm}^{-1}$.

In model B the sequence was subdivided into three sections, assuming linear accumulation within each section, and wigglematched to IntCal04 using the program Bpeat (Fig. 5(b) and (e)). Division levels were not fixed to certain depths, but were estimated automatically by the software. In addition, this match was solely based on the ${ }^{14} \mathrm{C}$ dates and prior information as in

Table 2 AMS ${ }^{14} \mathrm{C}$ measurements along core 2 from Hässeldala port

\begin{tabular}{|c|c|c|c|c|}
\hline $\begin{array}{l}\text { Sample } \\
\text { ID }\end{array}$ & $\begin{array}{l}\text { Laboratory no. } \\
\text { Ua- }\end{array}$ & Depth $(\mathrm{cm})$ & Dated material & $\begin{array}{l}{ }^{14} \text { C yr BP } \\
\pm 1 \sigma\end{array}$ \\
\hline $\mathrm{H} 4$ & 20510 & $322.15 \pm 1.15$ & Betula nana (L), Salix polaris (L), Salix sp. (W) & $12310 \pm 105$ \\
\hline H5 & 20511 & $319.75 \pm 1.25$ & Betula nana (L), Salix polaris (L), Salix sp. (L) & $12495 \pm 95$ \\
\hline H6 & 20512 & $317 \pm 1.5$ & Betula nana (L), Salix polaris (L), Salix sp. (L) & $12220 \pm 90$ \\
\hline $\mathrm{H} 7$ & 20513 & $314.6 \pm 0.9$ & Betula nana (L), Salix polaris (L), Salix sp. (L) & $12205 \pm 115$ \\
\hline H8 & 20514 & $312.45 \pm 1.05$ & Betula nana (L), Salix polaris (L), Salix sp. (L)* & $12375 \pm 115$ \\
\hline H9 & 20515 & $310.2 \pm 1.2$ & $\begin{array}{l}\text { Betula nana }(\mathrm{L}), \text { Salix polaris }(\mathrm{L}), \text { Salix sp. }(\mathrm{L}) \text {, } \\
\text { Dryas octopetala }(\mathrm{L})^{*}\end{array}$ & $12600 \pm 175$ \\
\hline $\mathrm{H} 14$ & 20516 & $298.45 \pm 1.05$ & $\begin{array}{l}\text { Betula nana }(\mathrm{S}, \mathrm{C}) \text {, Dryas octopetala }(\mathrm{L}) \\
\text { indet. }(\mathrm{L}) *\end{array}$ & $12355 \pm 190$ \\
\hline H15 & 20517 & $296.2 \pm 0.65$ & Betula nana $(\mathrm{L}, \mathrm{S}, \mathrm{C}, \mathrm{W})$, Dryas octopetala $(\mathrm{L})$ & $11920 \pm 90$ \\
\hline H16 & 20518 & $294.35 \pm 0.65$ & Betula nana $(\mathrm{L}, \mathrm{S}, \mathrm{C}, \mathrm{W})$, Dryas octopetala $(\mathrm{L})$ & $11990 \pm 110$ \\
\hline $\mathrm{H} 17$ & 20519 & $292.85 \pm 0.85$ & Betula nana $(\mathrm{L}, \mathrm{S}, \mathrm{C})^{*}$ & $11805 \pm 240$ \\
\hline H18 & 20520 & $291 \pm 1$ & Betula nana $(\mathrm{L}, \mathrm{S}, \mathrm{C}, \mathrm{W})^{*}$ & $11525 \pm 85$ \\
\hline $\mathrm{H} 20$ & 20522 & $287 \pm 1$ & Betula nana $(\mathrm{L}, \mathrm{C})$ & $11455 \pm 125$ \\
\hline H21a & 20523 & $285 \pm 1$ & Betula nana $(\mathrm{L}, \mathrm{S}, \mathrm{C})$, indet. (W) & $11245 \pm 95$ \\
\hline $\mathrm{H} 22$ & 20524 & $283.25 \pm 0.75$ & Betula nana (L, S, C), indet. (W) & $11275 \pm 95$ \\
\hline $\mathrm{H} 23$ & 20525 & $281.5 \pm 1$ & Betula nana $(\mathrm{L}, \mathrm{S}, \mathrm{C})$ & $11200 \pm 165$ \\
\hline $\mathrm{H} 24$ & 20526 & $279.5 \pm 1$ & Betula nana $(\mathrm{L}, \mathrm{S}, \mathrm{C})$, indet. (W) & $10935 \pm 80$ \\
\hline $\mathrm{H} 26+27$ & 20527 & $274.75 \pm 1.75$ & Betula nana $(\mathrm{L}, \mathrm{S}, \mathrm{C})$, indet. $(\mathrm{W})$ & $11070 \pm 135$ \\
\hline $\mathrm{H} 28$ & 20528 & $272.1 \pm 0.9$ & Betula nana (L, S, C), indet. (W) & $10935 \pm 80$ \\
\hline $\mathrm{H} 29$ & 20529 & $270.3 \pm 0.9$ & Betula nana $(\mathrm{L}, \mathrm{S}, \mathrm{C})$, indet. $(\mathrm{W})$ & $10515 \pm 75$ \\
\hline $\mathrm{H} 30$ & 16740 & $268.45 \pm 0.95$ & Betula nana $(\mathrm{L})$ & $10165 \pm 95$ \\
\hline H32 & 16745 & $265.5 \pm 1$ & Betula nana (L, C), indet. (W) & $10285 \pm 95$ \\
\hline H35 & 16747 & $259 \pm 1$ & Betula nana (L), indet. (W) & $9860 \pm 85$ \\
\hline H36а & 16750 & $257 \pm 1$ & Betula nana (L); indet. (W), charcoal & $10205 \pm 85$ \\
\hline $\mathrm{H} 37$ & 16752 & $255 \pm 1$ & $\begin{array}{l}\text { Betula nana }(\mathrm{L}), \text { Betula pubescens }(\mathrm{S}), \\
\text { Pinus sylvestris }(\mathrm{N})\end{array}$ & $9720 \pm 90$ \\
\hline H38 & 16761 & $253 \pm 1$ & Betula nana $(\mathrm{L})$, indet. $(\mathrm{W})$ & $9955 \pm 90$ \\
\hline H39 & 16766 & $251 \pm 1$ & Betula nana $(\mathrm{L})$, Pinus sylvestris $(\mathrm{N})$ & $9765 \pm 85$ \\
\hline
\end{tabular}

$\mathrm{L}=$ leaves and leaf fragments; $\mathrm{W}=$ wood fragments; $\mathrm{S}=$ seeds; $\mathrm{C}=$ catkin scales; $\mathrm{N}=$ needles; ${ }^{*}=$ heavily corroded plant remains. 

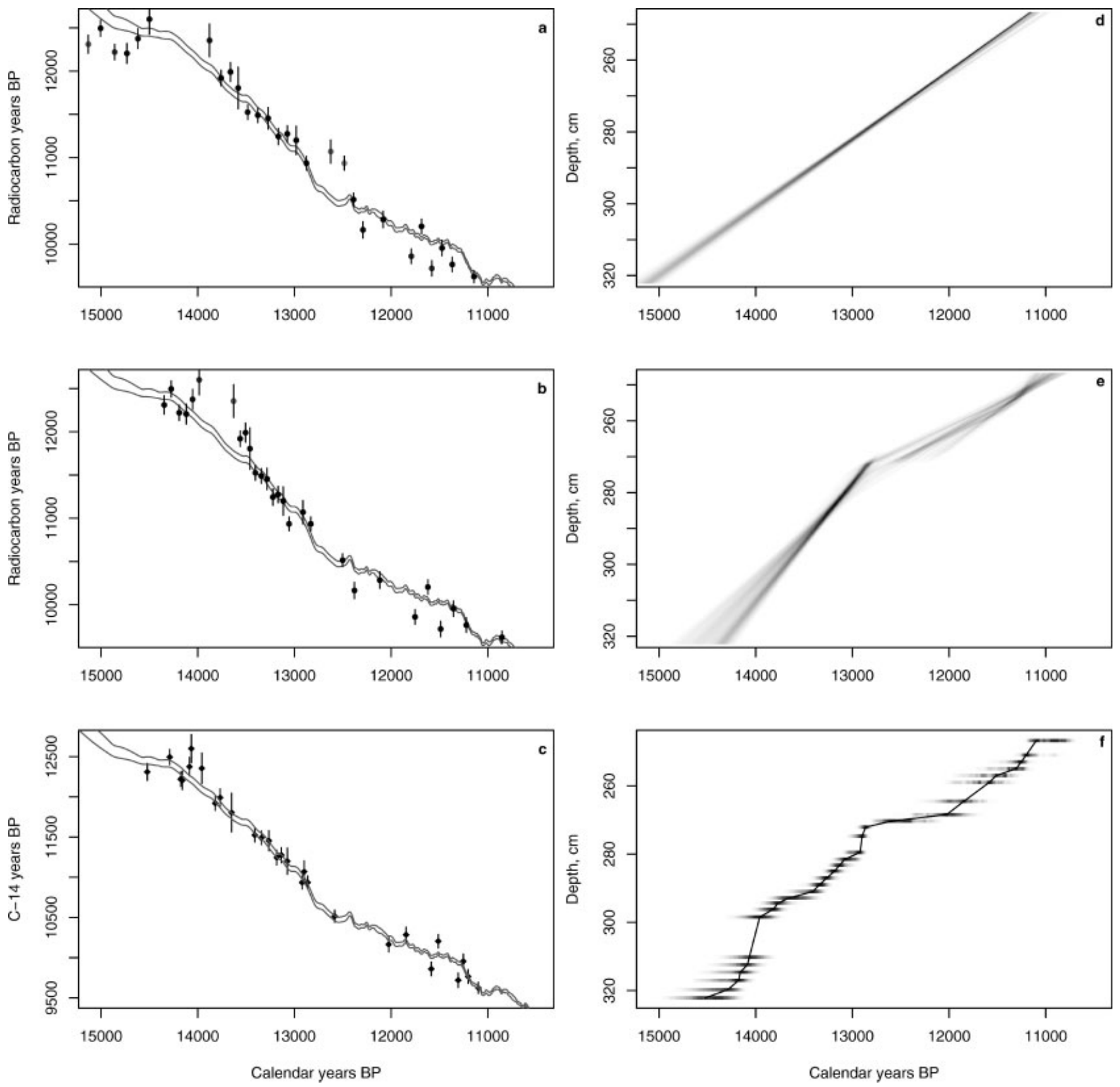

Figure 5 (a)-(c) Placement of the ${ }^{14} \mathrm{C}$ dates on the IntCal04 calibration curve (Reimer et al., 2004), using the programme Bpeat (Blaauw and Christen, 2005), (a) Model A, (b) Model B, (c) Model C. Calendar-year ages were given to the dated levels as proposed by the maximum posterior densities of their chronological ordering-constrained calibrated ranges. (d)-(f) Corresponding age model, where the grey scales indicate the likelihood of calendar ages for the dated levels. Darker colours indicate more likely calendar ages. The bold curve connects the highest posterior densities of the neighbouring levels, (d) Model A, (e) Model B, (f) Model C

model A, but included the following additional prior information: (i) very low dependency of the accumulation rate between the sections; (ii) hiatus lengths of up to ca. $100 \mathrm{yr}$ are possible, but shorter lengths are much more likely. This match resulted in a better fit than model $\mathrm{A}(F=92.71 \%$; Blaauw and Christen, 2005) (Fig. 5(b)), but gave the following outliers: Ua-16752, Ua-16740, Ua-20516 and Ua-20514. Only the last two samples contained corroded plant material and were thus suspected of being too old beforehand.

For model C, which was computed in Bcal (Buck et al., 1999), the entire sequence was matched against the IntCal04 calibration curve, assuming chronological ordering (Fig. 5(c) and (f)). Samples Ua-16747, Ua-16750, Ua-20515 and Ua20516 did not match the calibration curve within their 1 s.d. error bars, but only samples Ua-20515 and Ua-20516 had been assumed to be too old beforehand (Table 2).
The Bayesian modelling techniques described above use thousands to millions of so-called Markov chain Monte Carlo (MCMC) iterations to derive estimates of the parameters involved in an age model. Besides estimating calendar ages for the ${ }^{14} \mathrm{C}$ dated levels (i.e. the pollen zone boundaries HÄP 2/3, HÄP 3/4, HÄP 4/5 and Ḧ̈P 5/6), these methods can also be used to estimate the ages of non $-{ }^{14} \mathrm{C}$ dated levels (i.e. pollen zone boundaries HÄP $1 / 2$ and HÄP $6 / 7$, and tephras BT and HDT). For models $A$ and $B$, calendar age estimates for nondated levels within the ${ }^{14} \mathrm{C}$ sequence were straightforward as these models are based on piecewise, linear accumulation. For model C, calendar ages for the non-dated levels were estimated through providing relative information, i.e. Bcal was for example informed that the BT horizon is older than date Ua20516, but younger than Ua-20515. The tephra horizon AsT, however, is assumed to be located $2-3 \mathrm{~cm}$ above the ${ }^{14} \mathrm{C}$ dated 
part of core 2 (Fig. 4), and therefore needed an extrapolation to obtain an age estimate. For models A and B we simply extrapolated the MCMC-derived age-estimate to the required depth of AsT. We are aware that extrapolation is dangerous, and that the corresponding age estimate for AsT should be considered with caution. For model $\mathrm{C}$ a sensible upper age limit to constrain the age of AsT is missing. Therefore, its calendar age distribution could not be calculated for model C.

\section{Discussion}

Davies et al. (2004b) presented and discussed three different age models for the BT at Hässeldala port, based on visual wiggle-matching of the ${ }^{14} \mathrm{C}$ dates to the Cariaco Basin data set (Hughen et al., 1998, 2000) and on a Bayesian probability approach using the Cariaco (Hughen et al., 1998, 2000) and Lake Suigetsu (Kitagawa and van der Plicht, 2000) time series. These age models included fewer ${ }^{14} \mathrm{C}$ dates than the age models presented here and estimated the age of the BT to ca. 13900 Cariaco varve years BP (visual match) and 14 450-13 800 and 14 331-13667 cal. yr BP, respectively. The Bayesian approach adopted here includes wiggle-matching of a total of $28{ }^{14} \mathrm{C}$ dates to the new IntCal04 calibration curve (Reimer et al., 2004) under the assumptions of linear accumulation (Model A), linear accumulation between sections (Model B) and chronological ordering of ${ }^{14} \mathrm{C}$ dates (Model C).

Although the ${ }^{14} \mathrm{C}$ wiggle-match in Model $\mathrm{A}$ gives a rather nice fit to the radiocarbon calibration curve (Fig. 5(a)), the fit F of $83.83 \%$ is clearly below the $>90 \%$ fit suggested by Blaauw and Christen (2005). ${ }^{14} \mathrm{C}$ dates from the lower end of the sequence and between 12500 and 11000 cal.yr BP appear to be outliers. The grey-scale graph in Fig. 5(d) displays a very narrow uncertainty range, but considering that the age model only uses one single section to fit the dates to the calibration curve, this model might give an 'illusionary precise picture', as it might have forced dates to certain calendar ages. In Model B (Fig. 5(b)), which has a fit F of $93.45 \%$, two dates around $13500 \mathrm{cal}$. yr BP and dates around 12500 and $11500 \mathrm{cal}$. yr BP are the only outliers. As can be seen in Fig. 5(e), this model has rather large uncertainty ranges, which can be explained by the fact that it subdivided the sequence into three sections (with variable division depths), which in turn resulted in many different possible solutions. Model $\mathrm{C}$ is only constrained by chronological ordering (Fig. 5(c) and (f)) and results in a nice match of most ${ }^{14} \mathrm{C}$ dates. Outliers in this model are related to those ${ }^{14} \mathrm{C}$ measurements which were beforehand suspected of being too old.

The comparison between the three models (Fig. 5(a)-(f) shows, that model A gives narrow confidence intervals (Fig. 5(d), Table 3), but that it has some clear disadvantages (low fit $F$, unexpected outliers, assumption of linear accumulation of the entire core) over models B and C. Also the assumption of linear accumulation over long periods (e.g. an entire sequence), is not applicable for lake sediments, where sediment composition and sedimentation rates change rapidly and shorter hiatuses may be frequent. Models B and C show partly similar results but model $C$ uses fewer assumptions than model $\mathrm{B}$ and does not allow extrapolation beyond the dated range. The confidence intervals for pollen zone boundaries and tephra horizons (Figs 6 and 7, Table 3) provided by model $\mathrm{B}$ are, with a few exceptions, narrower than those of model $\mathrm{C}$. Thus, given the clear limitations of model $A$, we focus in the following discussion only on the calendar-year estimates given by models $\mathrm{B}$ and $\mathrm{C}$.

The boundary between the Older Dryas/Allerød regional pollen zone (HÄP 1/HÄP 2) is estimated to 1393413666 cal. yr BP (model B) or 14 226-13 808 cal.yr BP (model C) (Table 3), which corresponds approximately in time to the transition from Gl-1d to Gl-1c in the GRIP event stratigraphy

Table 3 Calendar-age estimates (95\% confidence intervals) for tephra horizons, local and regional pollen zone boundaries at Hässeldala port derived from age models A and B (see also Figs 4 and $5(\mathrm{a})-(\mathrm{f}) . \mathrm{BT}=$ Borrobol tephra, Indet $=$ unidentified tephra, HDT=Hässeldala Tephra, $\mathrm{AsT}=10-\mathrm{ka}$ Askja Tephra, $\mathrm{HÄP}=$ local pollen zones, $\mathrm{OD}=$ Older Dryas, $\mathrm{AL}=$ Allerød, $\mathrm{YD}=$ Younger Dryas, $\mathrm{PB}=$ Preboreal

$\begin{array}{lll}\text { Model A } & \text { Model B } & \text { Model C } \\ \text { cal.yr BP } & \text { cal.yr BP } & \text { cal.yr BP }\end{array}$

$\begin{array}{ll}\begin{array}{l}\text { Tephra horizons } \\ \text { BT }\end{array} & 14226-14105 \\ & 14165 \pm 60 \\ \text { Indet-1 } & 13063-12965 \\ & 13014 \pm 49 \\ \text { Indet-2 } & 12461-12335 \\ & 12398 \pm 49 \\ \text { HDT } & 11565-11299 \\ & 11432 \pm 133 \\ \text { AsT } & 11070-10750 \\ & 10910 \pm 160\end{array}$

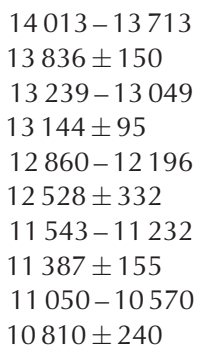

Local (and regional) pollen-zone boundaries End of HÄP $1(\mathrm{OD} / \mathrm{AL})$

$$
\begin{aligned}
& 14113-13917 \\
& 14015 \pm 98 \\
& 13315-13203 \\
& 13259 \pm 56 \\
& 12671-12559 \\
& 12615 \pm 56 \\
& 11733-11495 \\
& 11614 \pm 119 \\
& 11537-11271 \\
& 11404 \pm 133 \\
& 11229-10907
\end{aligned}
$$$$
11068 \pm 161
$$

$13934-13666$

$13800 \pm 134$

$13397-13239$

$13318 \pm 79$

$13065-12623$

$12844 \pm 221$

$11722-11406$

$11564 \pm 158$

$11422-11216$

$11319 \pm 103$

$11137-10805$

$10971 \pm 166$
HÄP 6/HÄP 7
$14259-13833$

$14046 \pm 213$

$13207-12964$

$13085 \pm 121$

$12906-12375$

$12640 \pm 265$

$11596-11164$

$11380 \pm 216$

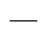

$14226-13808$

$14017 \pm 209$

$13391-13156$

$13273 \pm 117$

$13021-12841$

$12931 \pm 90$

$11876-11293$

$11585 \pm 292$

$11547-11128$

$11337 \pm 209$

$11235-10815$

$11025 \pm 210$ 

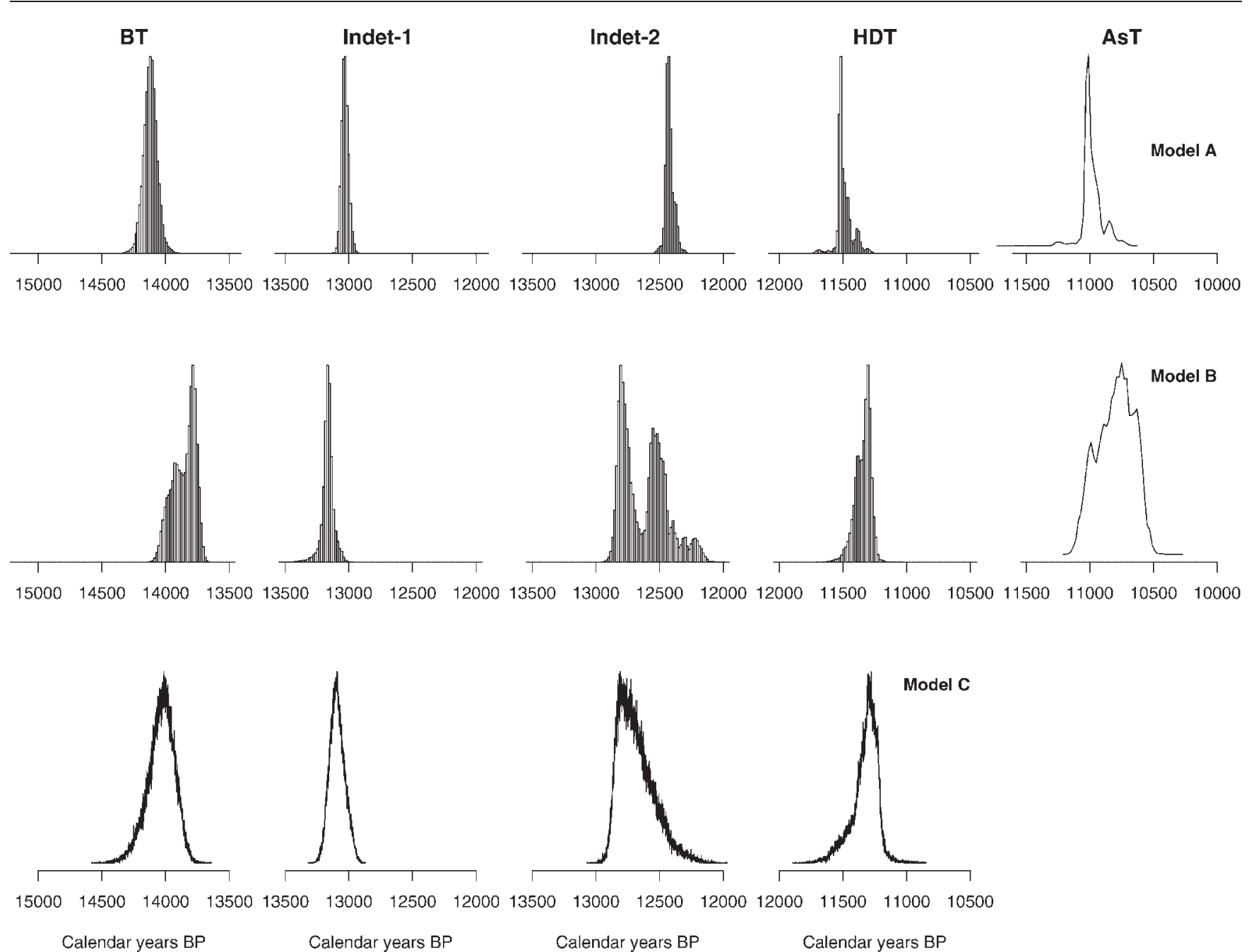

Figure 6 Age estimates for the different tephra layers according to age models A (top panel), B (middle panel) and C (lower panel); the black line connects the maxima of the constrained calibrated ranges. BT = Borrobol Tephra, Indet. = inidentified tephra, HDT = Hässeldala Tephra, AsT = 10-ka Askja Tephra

(Björck et al., 1998; Walker et al., 1999). The BT occurs at the very end of the Older Dryas pollen zone and is given an age estimate of 14013-13713 cal.yr BP (model B) or 1425913833 cal. yr BP (model C) (Fig. 6, Table 3). These estimates provide improved constraints on the age limits of the BT as compared to Davies et al. (2004b) and confirm the earlier hypothesis that the BT found at Hässeldala port is considerably younger than indicated from other European sequences (Lowe et al., 1999; Eiriksson et al., 2000). It seems to correspond in time with a 'Borrobol-like' cryptotephra, recently discovered in northwest Scotland and attributed to the early Allerød (Ranner et al., 2005).

The lower of the two unidentified tephras (Indet-1) falls within the regional Allerød II pollen zone (HÄP 3), just before the rise in TC content seen in all three sequences (Fig. 4) and is estimated to 13239-13049 cal. yr BP (model B) or $13207-$ 12964 cal. yr BP (model C) (Fig. 6, Table 3). The litho- and pollen stratigraphic position of the tephra horizon could indicate that it is a correlative of the Laacher See Tephra, which has been traced in, for example, Switzerland at the end of the Gerzensee Oscillation (Lotter et al., 1992, 1995).

The transition between the regional Allerød II/Younger Dryas pollen zone (HÄP 3/HÄP 4) has an age estimate of 1306512623 cal. yr BP (model B) or 13 021-12 841 cal. yr BP (model $\mathrm{C})$, which is close to the age for the boundary between GI-1a and GS-1 (Björck et al., 1998; Walker et al., 1999). The second unidentified tephra (Indet-2) correlates to the lower part of the regional Younger Dryas pollen zone and is estimated to 12 860-12 196 cal. yr BP (model B) or 12 906-12 375 cal. yr BP (model C) (Table 3). This age assignment makes it significantly older than the accepted age of the Vedde Ash $\left(10300{ }^{14} \mathrm{C}\right.$ yr BP or 12000 GRIP ice core yr BP; Grönvold et al., 1995; Birks et al., 1996; Wastegård et al., 1998). Without any geochemical information it is difficult to determine the origin of this tephra, although a tephra of early Younger Dryas age and older than the Vedde Ash has been identified in Sluggan Bog (Lowe et al., 2004).

The regional Younger Dryas/Preboreal (HÄP 4/Ḧ̈P 5) pollen zone boundary has an age estimate of 11 722-11 406 cal. yr BP (model B) or 11 876-11293 cal. yr BP (model C), which is close in time to the transition between GS-1 and the Holocene (Björck et al., 1998; Walker et al., 1999). The two youngest tephras (HDT, AsT) bracket the PBO and are recorded just below and above this climatic shift (Figs 3 and 4). The position of the HDT and AsT, before and after the PBO makes them potentially useful for time-synchronous correlations in various parts of Europe. The HDT is estimated to 1154311232 cal. yr BP (model B) or 11 596-11 164 cal. yr BP (model C) and the AsT to 11 050-10 $570 \mathrm{cal}$. yr BP (model B) (Table 3).

Constructing robust chronologies for Lateglacial lake sediment sequences such as Hässeldala port by the application of high-resolution ${ }^{14} \mathrm{C}$ dating, tephra horizons and Bayesian probability methods is evidently not a straightforward procedure. The errors associated with radiocarbon dating (Björck and 

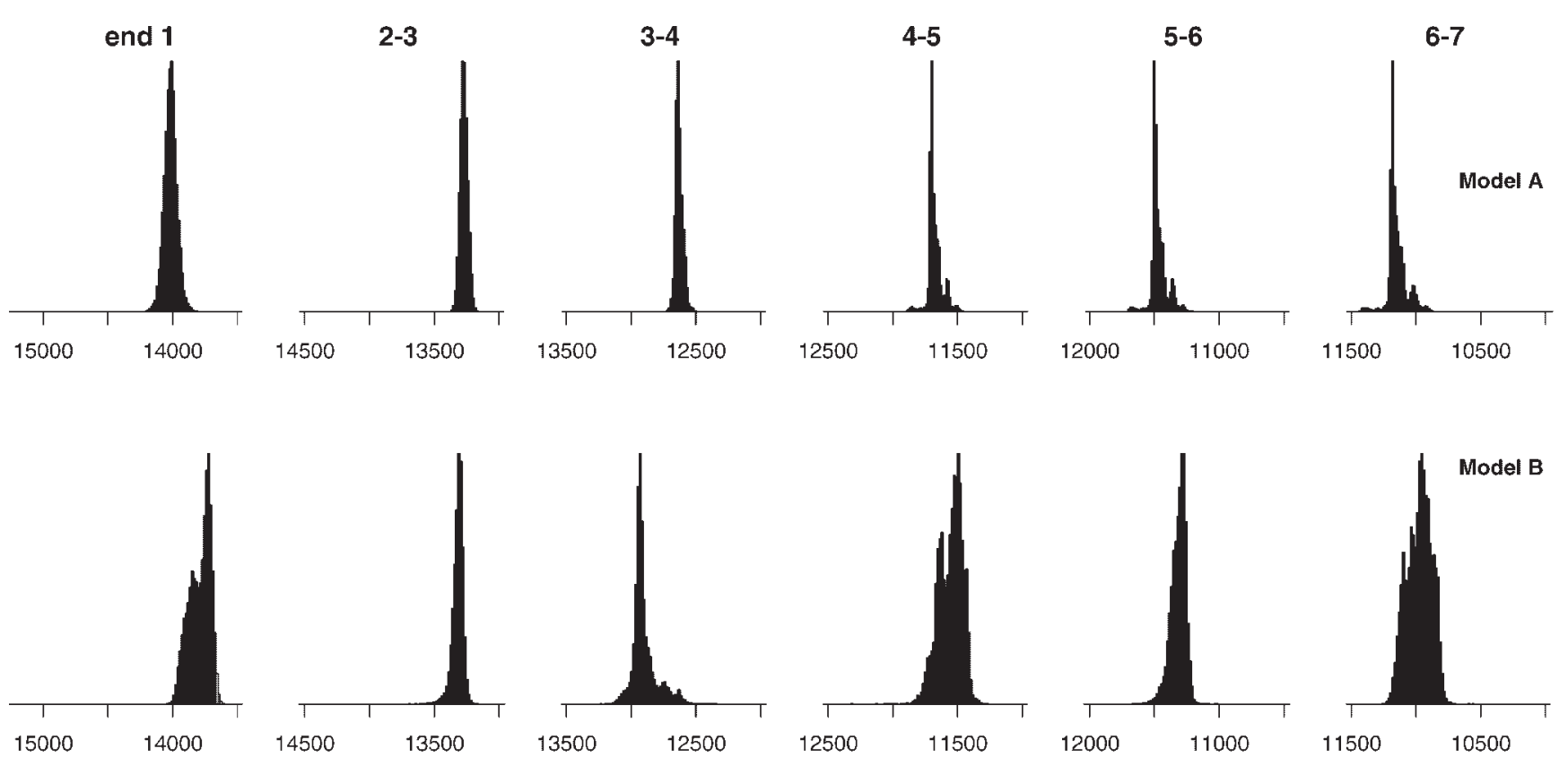
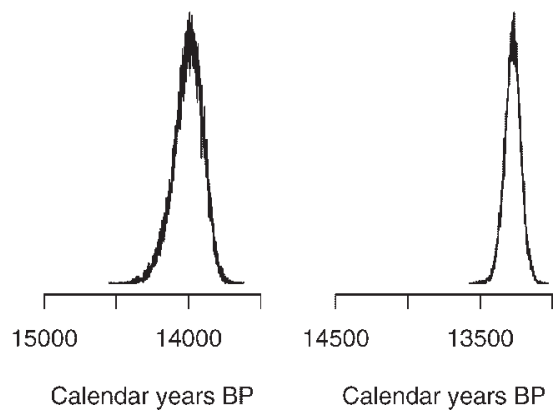
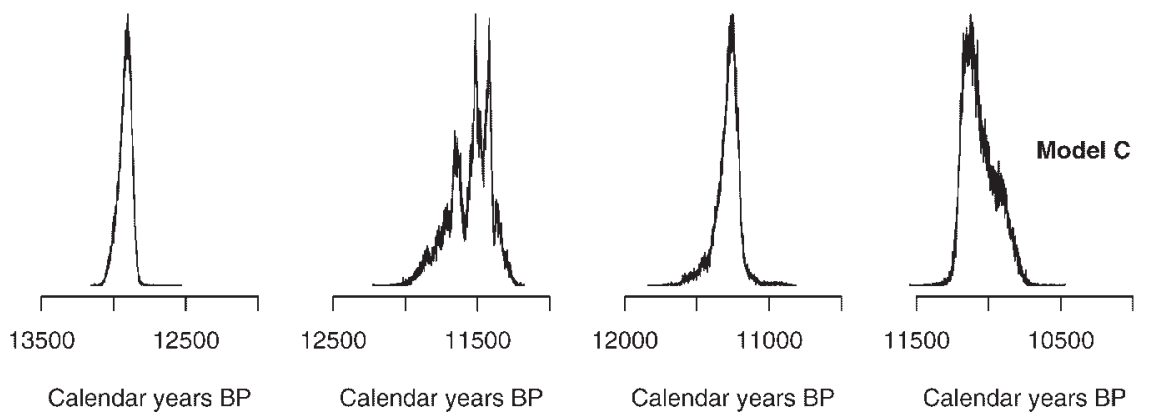

Figure 7 Age estimates for the local pollen zones according to models A (top panel), B (middle panel) and C (lower panel). See Fig. 3 for the pollen diagram

Wohlfarth, 2001) and calibration procedures are further confounded by uncertain sedimentation rates within lacustrine environments that may vary considerably due to topographic, climatic and environmental conditions. In addition, short hiatuses are often very difficult to detect and thus, in the absence of an annually laminated sequence, it is impossible to determine the sedimentation rates and the degree of variability with any degree of confidence during the Lateglacial period. Taking account of these limitations and including these as prior assumptions are critical for the establishment of valid and 'realistic' age models. This information is not always easy to incorporate into the exercise of constructing age-depth models and is as such often overlooked. The Bayesian probability methods outlined in this paper, however, in which these prior assumptions are incorporated represent the best available approach for the derivation of a robust high-resolution age-depth model for the Lateglacial period. Even so, this exercise has emphasised that it is difficult to solely use one model as limitations are recognised in all approaches. For instance, Model B might place too much confidence on the assumption of linear accumulation, an assumption which is probably unrealistic since rapid and large environmental changes occurred during this time period. On the other hand, the fact that ${ }^{14} \mathrm{C}$ ages could be imprecise would warrant against using model $C$, as this model perhaps places too much confidence on the dates being correct, and correspondingly infers changes in accumulation rate between each dated level. With our current level of information we cannot state which of the two models pro- vides the best age estimates. Accordingly the age ranges provided by models $B$ and $C$ are much larger, thus creating difficulties for precise correlations to other archives to determine leads/lags. Nevertheless, this exercise provides the best constrained, statistically reliable age estimates for the five tephra layers and the local pollen zones. Our results further support the position of the BT as found in southern Sweden at the end of the Older Dryas pollen zone and provide the first age estimates and pollen stratigraphic position for the 10-ka Askja and Hässeldalen tephras. This framework can be used for tracing these tephras in other palaeoclimatic sequences. Furthermore, our study highlights the dangers of solely accepting one age model for the derivation of a robust, statistically constrained chronology that can be compared to other palaeoarchives. Different age models will result in different age estimates and depending on the model that was chosen, published age estimates will probably be incompatible between sequences. A possible solution to this problem could be to radiocarbon-date a sequence with ultra-high resolution, to measure each radiocarbon sample long enough to increase its precision and to explore a number of different age-depth models so that various scenarios and factors can be incorporated into each model and evaluated individually.

In addition, tephra horizons can be employed as isochronous marker horizons on a continent-wide scale (Turney et al., 2004) which can preclude some of the uncertainties associated with the construction of ${ }^{14} \mathrm{C}$ age-depth models. Tephrochronology, however, is also subject to uncertainties as shown here in the 
case of the BT tephra. There is therefore, clearly a need for the application of a more diagnostic geochemical technique, for example, trace element analysis by Laser Ablation-Inductively Coupled Plasma Mass Spectrometry (Pearce et al., 2004) as well as deriving independent age estimates for these tephra horizons by their identification within the Greenland ice cores or annually laminated sequences. These approaches may then provide key time-synchronous correlations between different palaeoclimatic archives (Davies et al., 2004a; Mortensen et al., 2005). However, as the search for tephra and more specificially cryptotephra horizons is still at an early stage within such records, it is not currently possible to trace the same tephra horizons as tie points in all geological sequences due to variable dispersal patterns and taphonomic processes operating at a local scale. Consequently, radiocarbon dating is still an integral part of providing age estimates for tephra horizons and for constructing age-depth models during the Lateglacial period. Although the age ranges for the tephra horizons outlined here are large, the Bayesian probability methods followed provide the best constrained and statistically significant age estimates that are currently available given the uncertainties associated with constructing age-depth models during the Lateglacial period.

Acknowledgements We thank Ann Karlsson and Nagham Mahmoud for measuring the TC on cores 1-3, Sven Karlsson for help with the TILIA programme and Svante Björck for discussions. We appreciated the helpful review comments by John Pilcher.

\section{References}

Andresen CS, Björck S, Bennike O, Heinemeier J, Kromer B. 2000. What do ${ }^{14} \mathrm{C}$ changes across the Gerzensee oscillation/Gl-1b event imply for deglacial oscillations? Journal of Quaternary Science 15: 203-214.

Berglund BE, Ralska-Jasiewiczowa M. 1986. Pollen analysis and pollen diagrams. In Handbook of Holocene Palaeoecology and Palaeohydrology, Berglund BE (ed.). Wiley: Chichester; 455-484.

Berglund BE, Bergsten H, Björck S, Kolstrup E, Lemdahl G, Norberg K. 1994. Late Weichselian environmental change in southern Sweden and Denmark. Journal of Quaternary Science 9: 127-132.

Birks HH, Gulliksen S, Haflidason H, Mangerud J, Possnert G. 1996. New radiocarbon dates for the Vedde Ash and the Saksunarvatn Ash from western Norway. Quaternary Research 45: 119-127.

Björck S. 1979. Weichselian stratigraphy of Blekinge, SE Sweden, and water level changes in the Baltic Ice Lake. LUNDQUA Thesis, no. 7.

Björck S. 1984. Bio- and chronostratigraphic significance of the Older Dryas Chronozone-on the basis of new radiocarbon dates. Geologiska Föreningen i Stockholm Förhandlingar 106: 81-91.

Björck S, Möller P. 1987. Late Weichselian environmental history in southeastern Sweden during the deglaciation of the Scandinavian ice sheet. Quaternary Research 28: 1-37.

Björck S, Wohlfarth B. 2001. ${ }^{14} \mathrm{C}$ chronostratigraphic techniques in paleolimnology. In Tracking Evironmental Changes Using Lake Sediments, Last WM, Smol JP (eds). Kluwer: Dordrecht; 205-245.

Björck S, Kromer B, Johnsen S, Bennike O, Hammarlund D, Lemdahl G, Possnert G, Rasmussen TL, Wohlfarth B, Hammer CU, Spurk M. 1996. Synchronised terrestrial-atmospheric deglacial records around the North Atlantic. Science 274: 1155-1160.

Björck S, Rundgren M, Ingolfsson O, Funder S. 1997. The Preboreal oscillation around the Nordic Seas: terrestrial and lacustrine responses. Journal of Quaternary Science 12: 455-466.

Björck S, Walker MJC, Cwynar LC, Johnsen S, Knudsen KL, Lowe JJ, Wohlfarth B, INTIMATE members. 1998. An event stratigraphy for the Last Termination in the North Atlantic region based on the Greenland ice-core record: a proposal by the INTIMATE group. Journal of Quaternary Science 13: 283-292.
Björck S, Muscheler R, Kromer B, Andresen CS, Heinemeier J, Johnsen SJ, Conley D, Koc N, Spurk M, Veski S. 2001. High-resolution analyses of an early Holocene climate event may imply decreased solar forcing as an important trigger. Geology 29: 1107-1110.

Björck S, Koc N, Skog G. 2003. Consistently large marine reservoir ages in the Norwegian Sea during the Last Deglaciation. Quaternary Science Reviews 22: 429-435.

Blaauw M, Christen JA. 2005. Radiocarbon and peat chronologies and environmental change. Applied Statistics 54: 805-816.

Bond G, Kromer B, Beer J, Muscheler R, Evans MN, Showers W, Hoffmann S, Lotti-Bond R, Hajdas I, Bonani G. 2001. Persistent solar influence on north Atlantic climate during the Holocene. Science 294: 2130-2136.

Broecker WS. 1998. Paleocean circulation during the last deglaciation: a bipolar seesaw? Paleoceanography 13: 119-121.

Broecker WS. 2003. Does the trigger for abrupt climate change reside in the ocean or in the atmosphere? Science 300: 1519-1522.

Buck CE, Christen JA, James GN. 1999. BCal: an on-line Bayesian radiocarbon calibration tool. Internet Archaeology 7: http://intarch.ac.uk/ journal/issue7/buck

Davies SM, Branch NP, Lowe JJ, Turney CSM. 2002. Towards a European tephrochronological framework for Termination 1 and the Early Holocene. Philosophical Transactions of the Royal Society London 360: 767-802.

Davies SM, Wastegård S, Wohlfarth B. 2003. Extending the limits of the Borrobol Tephra to Scandinavia and detection of new early Holocene tephra. Quaternary Research 59: 345-352.

Davies SM, Mortensen AK, Baillie MGL, Clausen HB, Grönvold K, Hall VA, Johnsen SJ, Pilcher JR, Steffensen JP, Wastegård S. 2004a. Tracing Volcanic Events in the Greenland Ice Cores. PAGES News 12: $10-11$.

Davies SM, Wohlfarth B, Wastegård S, Andersson M, Blockley S, Possnert G. 2004b. Were there two Borrobol Tephras during the early Lateglacial period: implications for tephrochronology? Quaternary Science Reviews 23: 581-589.

Davies SM, Hoek WZ, Bohncke SJP, Lowe JJ, Pyne O'Donnell S, Turney CSM. 2005. Detection of Lateglacial distal tephra layers in the Netherlands. Boreas 34: 123-135.

Dugmore AJ, Larsen G, Newton AJ. 1995. Seven tephra isochrones in Scotland. The Holocene 5: 257-266.

Eiriksson J, Knudsen KL, Haflidason H, Henriksen P. 2000. Late-glacial and Holocene palaeoceanography of the North Icelandic shelf. Journal of Quaternary Science 15: 23-42.

Goslar T, Arnold M, Tisnerat-Laborde N, Hatté C, Paterne $M$, Ralska-Jasiewiczowa M. 2000. Radiocarbon calibration by means of varves versus ${ }^{14} \mathrm{C}$ ages of terrestrial macrofossils from lake Gosciaz and Lake Perespilno, Poland. Radiocarbon 42: 335-348.

Grimm EC. 1987. CONISS: a Fortran 77 program for stratigraphically constrained cluster analysis by the method of incremental sum of squares. Computers and Geosciences 13: 13-35.

Grimm EC. 1991. Tilia 1.12, Tilia Graph 1.18. Illinois State Museum, Springfield.

Grimm EC. 1992. Tilia and Tilia-graph: Pollen spreadsheet and graphics program. Programs and Abstracts, 8th International Palynological Congress, Aix-en-Provence, September 8-12, 1992. American Association of Stratigraphic Palynologists: Texas; 56.

Grönvold K, Óskarsson N, Johnsen SJ, Clausen HB, Hammer CU, Bond G, Bard E. 1995. Ash layers from Iceland in the Greenland GRIP ice core correlated with oceanic and land sediments. Earth and Planetary Science Letters 135: 149-155.

Gulliksen S, Birks HH, Possnert G, Mangerud J. 1998. A calendar age estimate of the Younger Dryas-Holocene boundary at Krakenes, western Norway. Holocene 8: 249-259.

Haflidason H, Eiríksson J, van Kreveld S. 2000. The tephrochronology of Iceland and the North Atlantic region during the Middle and Late Quaternary: a review. Journal of Quaternary Science 15: 3-22.

Hughen KA, Overpeck JT, Lehman SJ, Kashgarian M, Southon J, Peterson LC, Alley R, Sigman DM. 1998. Deglacial changes in ocean circulation from an extended radiocarbon calibration. Nature 391: 6568.

Hughen KA, Southon JR, Lehman SI, Overpeck JT. 2000. Synchronous radiocarbon and climate shifts during the last deglaciation. Science 290: 1951-1954. 
Kitagawa H, van der Plicht J. 2000. Atmospheric radiocarbon calibration beyond 11,900 cal BP from Lake Suigetsu laminated sediments. Radiocarbon 42: 369-380.

Lotter AF, Eicher U, Siegenthaler U, Birks HJB. 1992. Late-glacial climatic oscillations as recorded in Swiss lake sediments. Journal of Quaternary Science 7: 187-204.

Lotter AF, Birks HJB, Zolitschka B. 1995. Late-glacial pollen and diatom changes in response to two different environmental perturbations: volcanic eruption and Younger Dryas cooling. Journal of Paleolimnology 14: 23-47.

Lowe DJ, Hunt JB. 2001. A summary of terminology used in tephra-related studies. In Tephras, Chronologie, Archéologie, Juvigné E, Raynal JP (eds). Les dossiers de I'Archéo-Logis 1; 1722.

Lowe JJ, Walker MJC. 2000. Radiocarbon dating the last glacialinterglacial transition (ca. $14-9{ }^{14} \mathrm{C}$ ka BP) in terrestrial and marine records: the need for new quality assurance protocols. Radiocarbon 42: 53-68.

Lowe JJ, Birks HH, Brooks SJ, Coope GR, Harkness DD, Mayle FE, Sheldrick C, Turney CSM, Walker MJC. 1999. The chronology of palaeoenvironmental changes during the Last Glacial-Holocene transition: towards an event stratigraphy for the British Isles. Journal of the Geological Society, London 156: 397-410.

Lowe JJ, Hoek WZ, INTIMATE group. 2001. Inter-regional correlation of palaeoclimatic records for the Last Glacial-Interglacial Transition: a protocol for improved precision recommended by the INTIMATE project group. Quaternary Science Reviews 20: 1175-1187.

Lowe JJ, Walker MJC, Scott EM, Harkness DD, Bryant CL, Davies SM. 2004. A coherent high-precision radiocarbon chronology for the Late-glacial sequence at Sluggan Bog, Co. Antrim, Northern Ireland. Journal of Quaternary Science 19: 147-158.

Moore PD, Webb JA, Collinson ME (eds). 1991. Pollen Analysis. Blackwell: Oxford; $1-216$.

Mortensen AT, Bigler M, Grönvold K, Steffensen JP, Johnsen SJ. 2005. Volcanic ash layers from the Last Glacial Termination in the NGRIP ice core. Journal of Quaternary Science 20: 209-219.

Pearce NJG, Westgate JA, Perkins WT, Preece SJ. 2004. The application of ICP-MS methods to tephrochronological problems. Applied Geochemistry 19: 289-322.

Pilcher JR, Hall VA. 1992. Towards a tephrochronology for the Holocene of the north of Iceland. The Holocene 2: 255-259.

Pilcher JR, Hall VA, McCormac FG. 1996. An outline tephrochronology for the Holocene of the north of Iceland. Journal of Quaternary Science 11: 485-494.

Pilcher J, Bradley RS, Francus P, Anderson L. 2005. A Holocene tephra record from the Lofoten Islands, Arctic Norway. Boreas 34: 136-156.

Possnert G. 1990. Radiocarbon dating by the accelerator technique. Norwegian Archaeological Review 23: 30-37.

Ranner PH, Allen JRM, Huntley B. 2005. A new early Holocene cryptotephra from northwest Scotland. Journal of Quaternary Science 20: 201-208.
Reimer PJ, Baillie MGL, Bard E, Bayliss A, Beck JW, Bertrand CJH, Blackwell PG, Buck CE, Burr GS, Cutler KB, Damon PE, Edwards RL, Fairbanks RG, Friedrich M, Guilderson TP, Hogg AG, Hughen KA, Kromer B, McCormac G, Manning S, Bronk Ramsey C, Reimer RW, Remmele S, Southon JR, Stuiver M, Talamo S, Taylor FW, van der Plicht J, Weyhenmeyer CE. 2004. IntCal04 Terrestrial Radiocarbon Age Calibration, 0-26 cal kyr BP. Radiocarbon 46: 1029-1058.

Renssen H, van Geel B, van der Plicht J, Magny M. 2000. Reduced solar activity as a trigger for the start of the Younger Dryas. Quaternary International 71: 373-383.

Rose NL, Golding PNE, Battarbee RW. 1996. Selective concentration and enumeration of tephra shards from lake sediment cores. The Holocene 6: 243-246.

Turney CSM. 1998a. Extraction of rhyolitic component of Vedde microtephra horizons to correlate lake sediments. Journal of Paleolimnology 19: 199-206.

Turney CSM. 1998b. Isotope stratigraphy and tephrochronology of the last glacial-interglacial transition $\left(14-9 \mathrm{ka}{ }^{14} \mathrm{C} \mathrm{BP}\right)$ in the British Isles. PhD thesis, University of London.

Turney CSM, Harkness DD, Lowe JJ. 1997. The use of microtephra horizons to correlate Late-glacial lake sediment successions in Scotland. Journal of Quaternary Science 12: 525-531.

Turney CSM, Lowe JJ, Davies SM, Hall V, Lowe DJ, Wastegård S, Hoek W, Alloway B, SCOTAV members, INTIMATE members. 2004. Tephrochronology of Last Termination sequences in Europe: a protocol for improved analytical precision and robust correlation procedures (a joint SCOTAV-INTIMATE proposal). Journal of Quaternary Science 19: 111-120.

van der Plicht J, van Geel B, Bohncke SJP, Bos JAA, Blaauw M, Speranza AOM, Muscheler R, Björck S. 2004. The Preboreal climate reversal and a subsequent solar-forced climate shift. Journal of Quaternary Science 19: 263-269.

Walker MJC. 2001. Rapid climate change during the last glacialinterglacial transition; implications for stratigraphic subdivision, correlation and dating. Global and Planetary Change 30: 59-72.

Walker MJC, Björck S, Lowe JJ, Cwynar LC, Johnsen S, Knudsen KL, Wohlfarth B. 1999. Isotopic 'events' in the GRIP ice core: a stratotype for the Late Pleistocene. Quaternary Science Reviews 18: 1143-1150.

Wastegård S, Björck S, Possnert G, Wohlfarth B. 1998. Evidence for the occurrence of Vedde Ash in Sweden: radiocarbon and calendar age estimates. Journal of Quaternary Science 13: 271-274.

Wastegård S, Turney CSM, Lowe JJ, Roberts SJ. 2000a. New discoveries of the Vedde Ash in southern Sweden and Scotland. Boreas 29: 7278.

Wastegård S, Wohlfarth B, Subetto DA, Sapelko TV. 2000b. Extending the known distribution of the Younger Dryas Vedde Ash into northwestern Russia. Journal of Quaternary Science 15: 581-586.

Wohlfarth B, Possnert G, Skog G, Holmquist B. 1998. Pitfalls in the AMS radiocarbon-dating of terrestrial macrofossils. Journal of Quaternary Science 13: 137-145. 